\title{
Women Empowerment Through Udyogini Scheme In Karnataka
}

\author{
Prabhavathi P.O ${ }^{1}$ Dr. M G Basava Raja ${ }^{2}$
}

\begin{abstract}
Empowerment of women means economic development in terms of financial independence. A woman's role is not only important for taking care of her family but also for nation building. But she has been underestimated by not giving her ample opportunities to explore her abilities. Of late, due to various schemes of the Government aimed to encourage women to empower them has gained importance. Of all the schemes, Udyogini scheme is one of the schemes of the Government of Karnataka to improve the entrepreneurial skills and talent among women as owners and managers of economic assets. The present paper is an attempt to know the role and progress of Udyogini scheme .
\end{abstract}

Keywords:- Empowerment of women, entrepreneurial skills, Udyogini scheme

\section{INTRODUCTION}

Women are the main pillars of an economy, as her empowerment is essential for the society and economy as a whole. Empowerment means encouraging and developing skills for self-sufficiency, selfeconomic independence and growth oriented approach. In reality, in many countries either developed or developing women have a low socio- economic status. Gandhiji had once said society is an index of its civilization, train a man and you train an individual, train a woman and you build a nation. Empowerment means giving people power to do their jobs magnificently. This scheme allows women to learn how to face difficulties in life by becoming financially strong. In the entire world, women is the largest group which is excluded from the basic benefits of social and economic development. They are excluded from their own facilities. The women work participation rate, in India is less than half that of men.

1-Prabhavathi P.O Research Scholar, Department of Studies in Economics \& Co-operation, University of Mysore, Mysuru

2- Dr. M G Basava Raja Professor, Department of Studies in Economics \& Co-operation, Sir M Visvesvaraya P

G Centre, University of Mysore, Mandya

The five years plans aim to encourage empowering women, the Tenth Five-year Plan (2002-2007) adopted the strategy which allows 30 percent of the funds granted to help women and the eleventh five year plan also encouraged the chances of job creation through special financial intermediaries for the development of economic power of women and improve entrepreneurial skills.

\section{OBJECTIVES OF THE STUDY}

a) To study the importance of economic empowerment of women.

b) To study about the Udyogini scheme in providing economic status to women in Karnataka

c) To study the performance of Udyogini scheme in Karnataka.

\section{RESEARCH METHODOLOGY}

This study is based on secondary data.

\section{2 a) The importance of economic empowerment of women}

India's biggest problem where many people have a very poor economic profile which needs attention from the Governments. In India's development efforts to bring about perceptible change in the equality of life of the people. India huge population suffering from many problems like malnutrition, unemployment, and poor health care, this is very truth in case of weaker sections of the society namely women. In rural India, the high rates of illiteracy and low economic status of women underlie the need for increasing their financial position by providing income-generating assets. Provision to give to employment opportunities to rural women is one way to improve their socio-economic status. In most of the developing countries work towards the development of rural women and their active involvement in the main stream of development but at the same time, empowering women should be among the top priorities. In the year 1987, the Government of Karnataka established Karnataka State Women Development Corporation (KSWDC), as per the memorandum of association of 
(KSWDC),there is asset specified objectives according to which the corporation functions for the welfare of the women and their needs. Keeping these in view, the state government designed Udyogini scheme as a solution to all these rising needs of new women entrepreneurs.

\section{2 b) Udyogini scheme in providing economic status to women in Karnataka}

Udyogini is an innovative scheme, sanctioned by the Government of Karnataka through the state women development corporation during the year1997-98. Udyogini assists women in gaining self reliance through self employment in business and economic activities. Udyogini empowers women by providing loans through banks and other financial institutions. It also grants financial aid from the Karnataka State Women Development Corporation for undertaking small business activities. The financial aid is arranged through like commercial banks and RRBs. This scheme has gone a long way in preventing women entrepeneurs from taking financial help from money lenders at high rate of interest.

Under this scheme, the maximum cost is Rs.One lakh, age limit for beneficiaries is 18-45 years and family income limit to avail this benefit is Rs.40,000 per annum for all the women including those belonging to SC/ST. KSWDC provides a financial subsidy to women who have lost and deserted by their husbands and to those who are also physically handicapped. The entrepreneurial activities supported under Udyogini scheme include book binding, sari and embroidery works, ribbon making, dry fish trade, footwear manufacture, beauty parlour, gift articles, flower shops, vegetabes and fruit vending, canteen and catering, cut piece cloth trade, flour mills, toy making and photocopying service, fax paper manufacture, travel agencies, kirana shops, animal husbandry, photo studio, stationary shop, bangles, fish stalls, canteen services, provision stores, panipuri, chicken centres, poultry centres, mobile and service centres etc.

\section{2 c) Performance of Udyogini scheme in Karnataka}

Women's empowerment has been one of the development objectives in the sphere of economic objectives. With this objective in mind, the Udyogini scheme has been designed to promote income generating activities to women and the progress of Udyogini scheme is shown in the following table.

Table 1 :Progress of Udyogini Scheme in Karnataka.

\begin{tabular}{|l|l|l|l|l|l|}
\hline \multirow{2}{*}{$\begin{array}{l}\text { Sl. } \\
\text { No. }\end{array}$} & \multirow{2}{*}{ Year } & \multicolumn{2}{|l|}{ Physical(NOS) } & \multicolumn{2}{l|}{ Financial(Rs.lakh) } \\
\cline { 3 - 6 } 1 & $2009-2010$ & 5563 & 5530 & 495.00 & 460.50 \\
\hline & Target & Achievement & Target & Achievement \\
\hline 2 & $2010-2011$ & 9600 & 7910 & 1000.00 & 821.05 \\
\hline 3 & $2011-2012$ & 15518 & 14488 & 1500.00 & 1269.06 \\
\hline 4 & $2012-2013$ & 9332 & 9742 & 835.00 & 941.18 \\
\hline 5 & $2013-2014$ & 10500 & 2630 & 935.00 & 233.78 \\
\hline 6 & 2014.15 & 11598 & 5035 & 1030.00 & 295.00 \\
\hline 7 & $2015-16$ & 15000 & 9057 & 1100 & 825.00 \\
\hline
\end{tabular}

Source: Economic Survey of Karnataka (2015-2016), Government of Karnataka, Bengaluru

number of beneficiaries under the Udyogini scheme have been moderately increasing, the number of beneficiaries were very high during the year 2011-12, which reduced to 2630 beneficiaries during the year 2013-14 and later increased to 9057 number of beneficiaries during the year 2015-16. This shows that Udyogini scheme has been helping women belonging to different castes, who were deserted by their husbands and physically handicapped women by providing them a source of independent livelihood.

\section{IV. $\quad$ FINDINGS OF THE STUDY}

Udyogini scheme has been useful in improving entrepreneurial abilities to women especially in the rural areas, belonging to different castes and low economic groups by providing a maximum amount of Rs. One lakh as financial assistance. It has been found that women who have registered under the Udyogini scheme have 
taken up activities such as book binding, sari and embroidery works, ribbon making, dry fish trade, footwear manufacture, canteen and catering centresetc all of which have resulted in making them financially independent.

\section{CONCLUSION}

Undoubtedly, Udyogini scheme in Karnataka is helping down trodden women in improving their social and economic status. By availing this scheme it has built confidence amongst rural women and women belonging to different castes and religions. But what is needed that this scheme should be more effective by providing subsidies and also raising loan amount so that still a large group of women can take the benefit of this scheme.

\section{REFERENCES}

[1] Annual report (2012-2013), Department of Women \& Child Development, Government of Karnataka, Bengaluru

[2] Economic survey of Karnataka (2013-2014),Government of Karnataka, Bengaluru

[3] Economic survey of Karnataka (2014-2015), Government of Karnataka, Bengaluru

[4] Economic survey of Karnataka (2015-2016), Government of Karnataka, Bengaluru

[5] HemarjMeen\&KantaMeena(2011),Women Empowerment and Self Help Group, AadiPublications,Jaipur.

[6] Rudraswamy K. C. (2011), Empowerment of Women-Issues \& Challenges, Jnanodaya Publications, Mysuru 